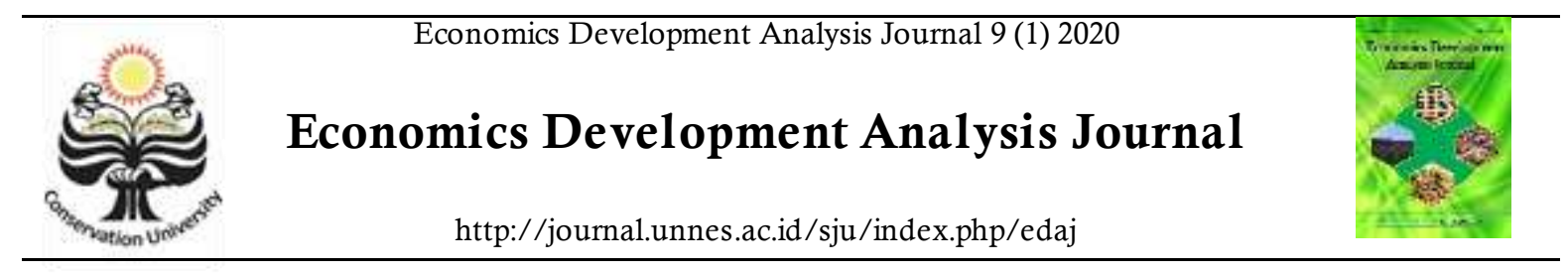

\title{
Model for Development of Copra Farmer Empowerment Through Institutional Training
}

\author{
${ }^{1}$ Yuan Fence Irala ${ }^{\bowtie},{ }^{2}$ Sucihatiningsih Dian Wisika Prajanti, ${ }^{3}$ Kardoyo \\ ${ }^{1,3}$ Economics Education Department, Universitas Negeri Semarang \\ ${ }^{2}$ Economics of Development Department, Universitas Negeri Semarang
}

\begin{tabular}{|c|c|}
\hline Article Info & Abstract \\
\hline $\begin{array}{l}\text { Article History } \\
\text { Received October } 2019 \\
\text { Accepted December } 2019 \\
\text { Published February } 2020\end{array}$ & $\begin{array}{l}\text { This study aimed to develop a model for the development of copra farmers' empowerment through } \\
\text { institutional training for farmer business groups which process coconut derivative products in } \\
\text { Asimiro Village, Loloda Sub-district, Halmahera Regency. The study employed Research and } \\
\text { Development approach. Meanwhile, there were two types of data used, namely primary and } \\
\text { secondary data. The results showed that problems faced by copra farmers in Asimiro Village were } \\
\text { limited capital, traditional technology, and marketing strategies that still depended on collectors. } \\
\text { There are several farmers' empowerment programs done through training and socialization } \\
\text { conducted in Asimiro, namely: 1) program for the development of coconut and onion cultivation } \\
\text { through the socialization from the Agricultural Technical Service of North Halmahera Regency; } \\
\text { and 2) Program Peningkatan Kesejahteraan Petani (PPKP) through training and socialization of "dapur } \\
\text { sehat" (healthy kitchen) conducted by the Village Community Empowerment Agency in } \\
\text { collaboration with the Family Planning Agency. The results of expert practitioner validation for the } \\
\text { model gained the percentage of } 80.76 \% \text {. Meanwhile, the academics validators gave } 74.99 \% \text { for the } \\
\text { model. It shows that the model for the empowerment of copra farmers in this study can be classified } \\
\text { into good category and valid. }\end{array}$ \\
\hline
\end{tabular}

\begin{tabular}{lr}
\hline Faculty of Economics UNNES, Sekaran, Gunungpati, & ISSN 2252-6965 \\
Semarang, 50119 & \\
E-mail: yuanirala@gmail.com &
\end{tabular}




\section{INTRODUCTION}

The development practices that have been going in Indonesia tended to emphasize economic aspects only. It causes the lack of advantages and quality in achieving a prosperous community level. This fact is confirmed by the data on poverty level. Moreover, the poverty seems to have no significant decrease in rural areas. Based on the data, the number of poor people in March 2017 were 27.77 million (10.64 $\%)$ with 17.10 million (61.57 \%) were located in rural areas, while the rest 10.67 million (38.42) were in urban areas.

The core of people-centered development is realized by empowerment that leads to community independence. Community empowerment is seen as a development activity that does not only emphasize the economic sector, but also "an economic development concept that covers social values, namely those that are people-centered, participatory, empowering and sustainable". (Chambers in Kartasasmita, 1996).

One of regencies that runs a community empowerment program is North Halmahera Regency. Through the Balai Pendidikan Masyarakat Desa (BPMD), North Halmahera Regency launched a farmer business development and empowerment Program Peningkatan Kesejahteraan Petani (PPKP) via local resources-based productive activities. (North Halmahera LKPJ, 2016). North Halmahera Regency has plentiful local resources potential, namely coconut plantations. Coconut plantations are the main livelihoods that become a source of income for people in this area. The total area of coconut plantations in 2015 reached 49,262 hectares, with a total production of 71,949 tons per year.

Similarly, Asimiro Village in North Loloda Sub-district, North Halmahera Regency, also has considerable coconut commodity potential. This commodity is the main livelihood that become a source of income for farmers in this village. The area of coconut plantation owned and processed by copra farmers is a minimum of $0.65-1.0$ hectares and a maximum of 2.1-3.5 hectares per family head (Patty, 2011). Even though the area of coconut plantations is quite extensive, the level of productivity of coconuts produced by copra farmer business was still low. The low productivity of coconuts was caused by the traditional way of production, namely the products were in form of coconut grains and copra commodities. The production caused the low selling value of the coconut and farmers' income (Lay \& Pasang, 2012). Moreover, the utilization of by-products such as shells and coconut husks have not yet been explored and the by-product was only used as waste / garbage. Whereas, coconut shell and husks fiber waste are feasible to be developed, both from the aspect of production and into products that have economic value.

The limited knowledge and skills of coconut products diversification, low level of entrepreneurship motivation, and the unavailability of socio-economic institution in terms of management, capital, market, and partnership with farming groups made copra farmers in a disadvantage position in developing farming businesses. Aminah et al.'s study (2015) about factors influencing farmers' empowerment in Eastern Indonesia mentions that agricultural development has not created empowered farmers. It is because most farmers have low access to development resources.

Sutardi et al (2017) in their study examined community empowerment to realize integrated and sustainable coconut processing Micro, Small, Medium Enterprise (MSME), and indicated that the implementation of community empowerment programs in TNS Waipia Subdistrict, Central Maluku Regency is able to create new entrepreneurs and four joint Kelompok Usaha Bersama (KUB), namely VCO and two Kelompok Usaha Bersama (KUB) of "nata de coco" that is made of raw coconut water as well as the production of briquettes made of coconut shell charcoal.

Community empowerment is a concept of economic development that covers social values. This concept reflects the new paradigm of development is "people-centered, participatory, 
empowering and sustainable" (Mardikanto \& Soebiato, 2017).

The position of coconut farmers in various development patterns such as Perkebunan Iti Rakyat (PIR) is only used as a producer or supplier of raw materials for industrial needs. This development pattern has not been able to strengthen the position of farmers in coconut agribusiness (Lay \& Tide, 2012). The weak empowerment of coconut farmers was because of the difficulty to express opinions in making beneficial decisions to deal with other farmers / farmer groups who also use coconut as a source of economic activity.

In relation to the above statement, Suryonotonegoro, (Lay \& Tide, 2012) states that the empowerment of farmers can be done in two stages, namely the recovery phase and the development stage. The recovery phase requires a mentoring program to educate and motivate farmers to improve productivity and efficiency in farmer business processing. It consists of the development of farmer groups as a communitybased organization through the development of togetherness principles and the provision of abilities to solve problems and make decisions. Meanwhile, the development phase is directed toward the development of farmer business, agroindustry and economic institutions. Farmer institutions need to be established with the aim of providing services to farmers who are members in groups and lobbying the government in association with the development of agricultural businesses.

Related to the role of institutions in community empowerment activities, Mardikanto and Soebiato (2017) suggest that the availability and effectiveness of institutions will greatly influence the success of community empowerment activities. Hishiyama (2013); and Sadjad (2000) say that the model of sustainable empowerment to improve socio-economic conditions and help the provision of education should have the empowerment to be more directed towards the growth of agribusiness engineering so that farmers in the village can be reliable business actors and finally can become the center of prosperous rural community business. The model for the empowerment for copra farmers and institutional empowerment is important in order to encourage copra farmers to organize themselves and gather in a business forum to synergize the strength and potential of the farming community. Thus, there is a need to create a model for the empowerment of copra farmers that is programmed and comprehensive as well as is carried out continuously through a system that considers local wisdom. Therefore, this study aimed to develop model for the development of copra farmer empowerment through institutional training for farmer business groups focusing on the derivative products of coconut in Asimiro Village, Loloda Sub-district, North Halmahera Regency.

\section{RESEARCH METHOD}

This study was conducted using Research and Development approach. The activities of developing, validating results and creating products in this study were done through empowerment. The empowerment activity in this study was realized by empowering copra farmers through an institutional training for farmer business groups focusing on the derivative products of coconut. As a results, copra farmers will not only process coconut meat into copra commodities, but also coconut shell and husks waste as economically valuable products, so these additional products can be used as a source of income or new business for copra farming communities in Asimiro Village, North Loloda Sub-district, North Halmahera Regency. The application of Research and Development aimed not only to bring change, but also to solve the problems faced by copra farming communities and to increase work productivity in carrying out farming activities.

There were two types of data used in this study, namely primary data and secondary data. The primary data in this study were derived from interviews with key informants, copra farmers, experts and field practitioners. Meanwhile, the secondary data sources were obtained from BPS and literature studies on previous research (scientific journals, theses and dissertations), books and other supporting documents. The 
secondary data was realized in the study of community empowerment through the model of farmer empowerment, information on the use of coconut shell, population, education level of the local community, and other supporting data.

The main subjects in this study were copra farmers in Asimiro Village, field practitioners (taken from the organizers of farmers' empowerment programs) and experts (academics). The research subjects were selected purposively or intentionally. For more, the data collection at the research stage used qualitative and quantitative approaches. The qualitative data were collected by conducting in-depth interviews with key informants and conducting observations. On the other hand, the data collection in quantitative approach was done by questionnaire.

The validity test in this study was conducted on the model for the coconut shell waste utilization-based skills training. The test was done using Delphi technique. Some experts were chosen to examine the data by filling out validation questionnaire that has been prepared in advance. The minimum criterion for the three experts was the doctorates title or even professorship. The model validity testing was also done by selecting validators from practitioners. On the one hand, the data analysis method used in this study used a mixed method which was qualitative and quantitative. Qualitative analysis in this study consisted of data reduction, data presentation and conclusion drawing. The data reduction was done by discussing with people who were considered experts. Furthermore, the data presentation was performed after the data reduction activities, in this case was in the form of a brief description, charts and relationships between categories. The last were conclusions drawing and verification. Credible conclusions are conclusions supported by valid and consistent evidence.

For quantitative analysis, this study used statistical assistance, namely by calculating the total score from the validation of questionnaire, and creating scores criteria according to the validity criteria of the empowerment model. The data analysis of the validation sheet covered the following steps: (1) Recapitulating all validator statements, (2) Finding the mean of each indicator of all validators, (3) Finding the mean of each aspect of all validators, (4) Finding the mean of all validators (5) Matching the total mean with the specified category. The weighting formula for determining the level of validity of the model is as follows:

$$
\begin{gathered}
\begin{array}{c}
\text { Percentage } \\
=\frac{\text { (Total Questionnaire Answers) }}{\text { Maximum Scores }} \times 100 \% \ldots . . . . . . . . . .(1)
\end{array} \\
\text { In addition, to analyze the validation }
\end{gathered}
$$
results from the experts, the researchers made a comparison using the following table of validity categories:

Table 1. Criteria for Feasibility / Validity of the Empowerment Model

\begin{tabular}{lll}
\hline $\begin{array}{l}\text { Level of } \\
\text { Achievement } \\
(\%)\end{array}$ & $\begin{array}{l}\text { Classifica } \\
\text { tions }\end{array}$ & \multicolumn{1}{c}{ Criteria } \\
\hline $81-100$ & $\begin{array}{l}\text { Very } \\
\text { Good }\end{array}$ & $\begin{array}{l}\text { No } \\
\text { Revision/Valid } \\
\text { No Revision } \\
\text { /Valid }\end{array}$ \\
$61-80$ & Good & $\begin{array}{l}\text { Revision/ No } \\
\text { Revision } \\
\text { Revision / No } \\
\text { Revision / No } \\
\text { Revision / No } \\
\text { Revision }\end{array}$ \\
$21-40$ & Fair Bad \\
$0-20$ & Very Bad \\
\hline
\end{tabular}

Source: Zunaidah, 2016.

\section{RESULTS AND DISCUSSION}

The Characteristics of Copra Farmers, based on the results of observation, there were 256 Asimiro family head work as copra farmers and farm laborers. Commonly their age iss around 36-45 years old. Meanwhile, their background of education is at the elementary school, junior high school, and some even did not finish the elementary school. The potential of copra in Halmahera Regency itself is actually very abundant, due to the abundance of coconut yields during the harvest season (Rusno et al., 2014; Budiman et al., 2015; La Idin, 2016). The huge potential of coconuts should be utilized as much as possible for the welfare of the people. 
Coconut farmers should be given the opportunity to enjoy better yields (Wardanu \& Anhar, 2011; Pohan et al., 2013). However, after these people were interviewed, it was known that copra farmer business used traditional processing and not economical, namely the products were still in form of coconut grains and copra commodities.

The copra commodity is in form of dried coconut made by smoking and drying it by the sun. The production of this commodity is done four times in a year or once in every four month (quarterly system). To produce one ton of copra, farmers or landowners need 10 - 12 laborers to work in groups. Meanwhile, for the cost, they need 22-25 percent of the selling price. If the land is farmed out by farm laborers, the proceeds from copra commodity selling will be halved, $50 \%$ for the landowners, while another $50 \%$ for the farm laborers. In details, the income earned from copra farming in every quarter was IDR 1.8-2.0 million/ ton, depending on the selling price at the copra traders. This fact was stated by $\mathrm{Mr}$. Hendrik Seloha in the following excerpt:

"We work here every quarter. If the selling price at the traders is high, we can earn much money. However, if the collector traders buy copra at a low price, the amount of coconut labor costs will be insufficient. In addition, the current

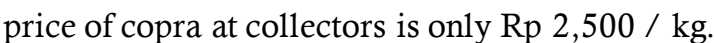
If we only farm 1 ton of copra, we will maximally earn IDR 1.8-2.0 million."

From the observation and interview, copra business has not been able to support the farmers' daily need, so they also did side jobs such as working as construction workers, bamboo farmers, and also fishermen. Though the potential of coconut in Halmahera is very abundant and it should be a good opportunity to develop copra products that are more economical (Papoko, 2013). Additionally, copra farmers had a great desire to develop and or process coconut shell and coconut husk waste into economically valuable products, but they did not have the ability to obtain and know the skills or knowledge as well as the inability to access information to develop the waste. This is in accordance with what was stated by Mr. Hendrik Seloha during the interview at the coconut plantation, as follows:

"The copra farmers here are very keen to develop shells into shell charcoal. It is because now we heard that currently the price of shell charcoal in Manado is very expensive. However, we have a difficulty in obtaining information about how to make shell charcoals. If we knew how to make it, we could earn much money by selling the shell charcoal." Other obstacles were from the absence of active roles from the agricultural technical service in providing assistance or even guidance, lack of information access among copra farmers with the agricultural technical agency and vice versa. Somehow, it looked like the farmers were left alone.

The capital in the copra farming business run by copra farmers in Asimiro village generally came from their own capital or self-supporting capital. The farmers did not spend too much capital (in the form of money) every time they carried out the processing of copra coconut because there were some elements of activities that the copra farmers could undertake themselves, such as mowing the coconut grass and making a copra smoked coconut. For more, they strongly needed capital when copra coconuts enter the phases of panjat kelapa (climbing up the coconut trees to harvest the coconuts), splitting and picking up coconut meat. To do so, the copra farmers needed 10-12 people. Commonly, the farmers obtained capital from owing or borrowing to collectors by a contract system or an agreement between copra farmers and collecting traders. It was revealed when the writer conducted an interview with Mr. Pilemon Dilago. The excerpt is as follows, "All copra farmers in this are, if they need capital for the cost of copra coconut production, they borrow it from entrepreneurs in the contract system. We have never made a loan outside the entrepreneurs or any party, even borrowing from the bank. It is because the procedure is too difficult and people are afraid to be able to repay the capital loan ".

Generally, copra farmers in Asimiro village rely heavily on copra collectors, both in terms of farming capital, copra sales and even 
daily living expenses. As a result it makes them helpless. This is in line with research conducted by Rifa'i et. al (2019) who said that the dependence of copra farmers is very high because they are not able to market the products they produce independently. In addition, the products they produce are also not able to penetrate the broad market if marketed alone. The institutions of coconut agribusiness in Asimiro Village are farmers, traders, coconut processing and traders. Coconut produced from farms owned by farmers is sold to collectors. Farmers and collector traders have been bound in contracts, so farmers are bound to collector traders. The contract between the farmer and the collecting trader occurs because of the farmers' limited access and direct information to the market. Moreover, the collector also has a contract with a trader. The weak partnership of copra farmers and the ability to sell their products to industry is also one of the causes of farmers' dependence on copra collectors (Rosidi et al, 2017).

With the contract system, the monthly income level of farmers tends to be low. The contract system is more profitable for collectors and wholesalers. Even though in the results (business analysis) showed that the copra coconut farming can be run well, this business has not yet been able to improve.

The low income received by the farmers was caused by the practice of monopsony by large traders or local coconut factories in the coconut trading system. For more, the price was set unilaterally, so the practice is only beneficial for buyers. This condition often causes farmers to abandon their plants and makes the productivity declines. (Chaerani, 2016). In addition, copra produced by local farmers also often has poor quality so that prices on the market are very low. That is caused by unpredictable weather changes so that the copra produced has a less competitive quality (Pohan et al, 2013). The model for the development of copra farmer empowerment in Asimiro Village was made based on the results of interview done in the field study (information collection phase. It was known that there were several community empowerment programs through training and socialization conducted in Asimiro Village, namely: 1) program for the development of coconut and onion cultivation through the socialization from the Agricultural Technical Service of North Halmahera Regency; and 2) program for the improvement of smallholder welfare (PKPK) through training and socialization of "dapur sehat" (healthy kitchen) conducted by the Village Community Empowerment Agency in collaboration with the Family Planning Agency. The following are excerpts from interviews with an informant named Berty Sikawi, S.E. as the Coordinator of Empowerment Village of North Loloda Subdistrict level on June 8, 2018:

"Training? We did it last year (2016) in Asimiro Village. We held the training and socialization on healthy kitchens ... However, a training in processing coconut shells and husks has not been done. Meanwhile, a socialization on coconut cultivation, seedlings and fertilizer assistance has ever been conducted. Other than these, we have never done any. " The statement was also supported by statements from supporting informants, namely village assistants, and village chief, and other stakeholders.

"We (the people of Asimiro Village) have never received any training on the processing of coconut shell and husks. It was only a socialization on coconut... staffs from the regency happened to conduct a socialization on coconut seeds, and gave onion fertilizaers... this kind of socialization usually takes place once in a year, and only be conducted when there is a budget." The implementation of training in the effort to empower coconut farmers in Asimiro was related to the processing of coconut shells and husks has never been carried out. The implementation of training in the effort to empower farmers in the village is usually carried out by the Agricultural Technical Service of North Halmahera Regency through socialization in the village. 


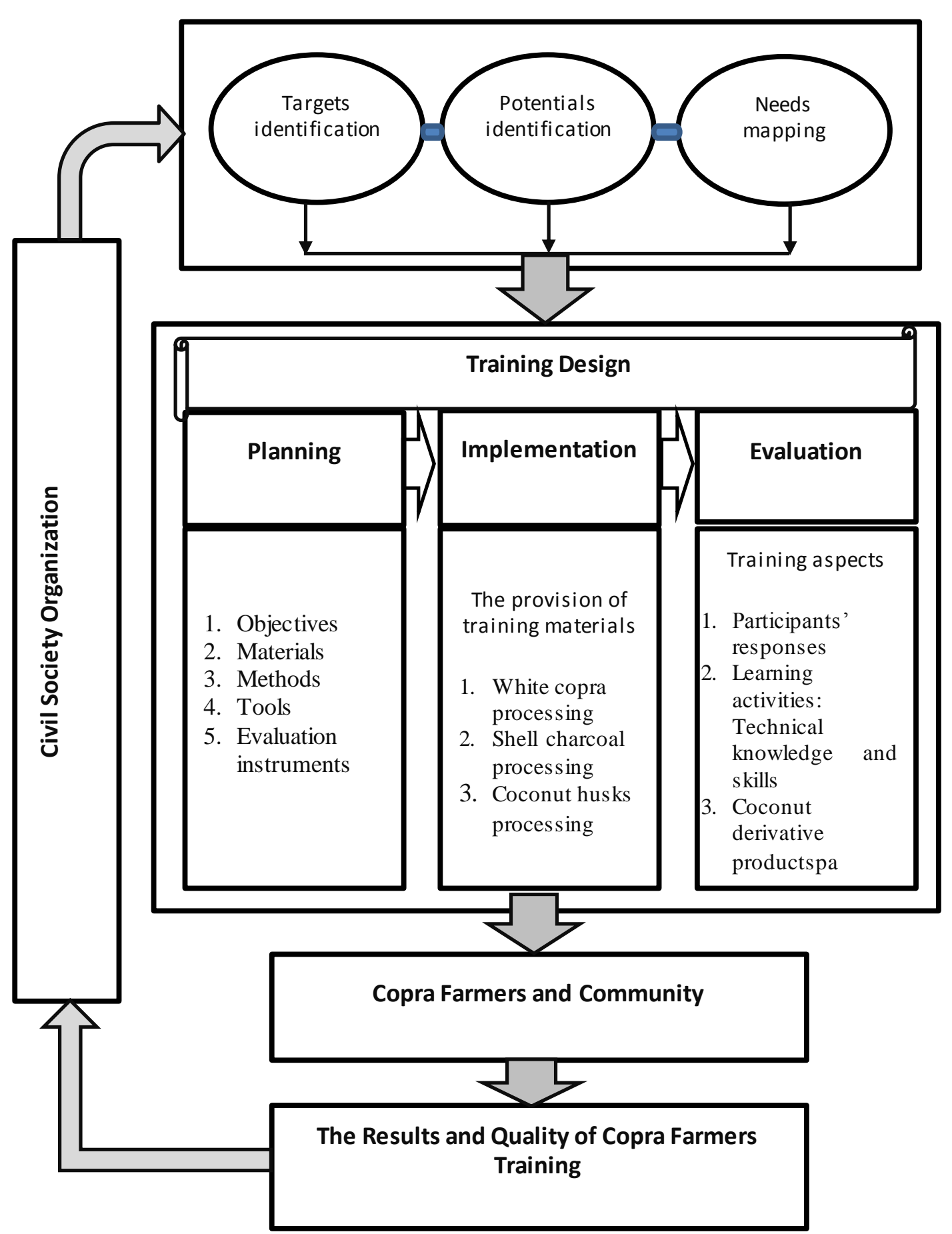

Figure 1. The Conceptual Model for the Empowerment of Copra Farmers through Institutional Training for Copra Farmers Group

The Design of the Conceptual Model for the Empowerment of Copra Farmers through Institutional Training for Farmer Business Groups, the design of the conceptual model for the empowerment of copra farmers in Asimiro Village was made based on the follow up of the empirical facts from the results of preliminary study, namely by considering problems, needs, and local potentials or the local area that is the utilization of coconut resources.

Besides, the design was also based on the existing training model and the analysis of factual 
model of the empowerment of farmers' community that has been conducted by the Regional Government of North Halmahera Regency in Asimiro Village.

Further, the development of this model referred to the conceptual model design developed by Sumpeno that is called as RapidTraining Design (RTD), and the combination of process process model training and communitybased Sheltered Workshop models. This quick training design model was chosen because this model was considered as a way to not only obtain knowledge, attitudes, and skills regarding the job being undertaken, but also to optimize participants' potentials by providing choices, and situations that may enable to study in a comfortable and joyful processes so that the skills that have been built can be a capital in mastering new things.

Process model training emphasizes several important aspects, namely facilitator, participants, learning process, training materials, and participants' background. This model was combined with community-based Sheltered Workshop model. The stages on process model training stops in evaluation stage, namely assessing the result of training. Meanwhile, the community-based Sheltered Workshop does not only provide vocational skills training, but also promotion and marketing of the products resulted from the workshop.The framework for developing a conceptual model for the empowerment of copra farmers through institutional training for farmer business groups which process coconut derivative products can be seen on figure 2 . The design was manifested into two frames, namely: preliminary study and training design. The preliminary study was done to identify targets, potentials, and map needs. Meanwhile, the study design consisted of three steps, namely: 1) planning, including formulating the purposes of training, materials, methods, tools, and evaluation instruments; 2) implementation, covering learning process where facilitators deliver training materials by referring to the training purposes and materials, and; 3) evaluation, consisting of examining participants' skills and assessing the products of the training.
Other than these three main steps, the developed model also mentioned products promotion activities.

The following is the visualization of the conceptual model for the empowerment of copra farmers through institutional training for farmer business groups. The development of copra farmers' empowerment through institutional training in processing coconut derivative products consisted of two stages. First, the development of model design components. Second, the validation of the conceptual model design for training by experts (academics) and practitioners. The aim of developing a model for the empowerment of coconut farmers through institutional training for farmer business groups focusing on the derivative products was to obtain a valid, effective and reliable model for empowering copra farmers through training.

The general objective of institutional training in farming groups was to empower copra farmers in rural areas. Meanwhile, the specific goal was not only to increase knowledge (cognitive), but also to grow and increase awareness (attitude) and new skills that are able to change the behavior of individuals/ groups towards efficient, productive and marketoriented business activities, namely to produce coconut commodities that can be processed into alternative products that have economical values. The model for the empowerment of copra farmers though training covered several components. Those components were related each other. In details, the main components in the model design consisted of:

Preliminary Study, at this stage the community empowerment institution / agency conducted observations to identify potentials, problems and needs mapping of the farmer community. Analysis and needs mapping for the training design in this model was done by direct observation. The observation was done by doing natural observations about the conditions, problems and needs of the local community. The training design needs were also assessed based on the products to be developed, namely copra, shell charcoal, and coconut husks products. This was done because the processing of coconuts in 
Asimiro Village was still traditional, namely coconut meat was only used as the commodity of copra while the shell and coconut husk were just thrown away as garbage.

Training Design, the results of preliminary study were used as a guide for designing the training. The design consisted of planning, implementation, and evaluation.

The training planning to empower copra farmers was started by designing training curriculum. Curriculum means a set of plan and ways to administer objectives, contents, and teaching materials. It is also a guide to achieve learning objectives. The planning covered several activities, namely formulating objectives, compiling material, methods, tools and compiling evaluation instruments to assess the success of training.

Implementation is essentially a process of teaching and learning activities in training where the facilitator presents the training materials systematically and practices making products. The reference of the learning process in this training was the training material and facilitator. The learning scenario was done by lecturing and practice. Next, the participants were given tasks or projects to make coconut derivative products, namely, good quality white copra, shell charcoal, and coconut husks. The learning and process of the manufacturing processes were detailed in the training guide.

Training evaluation is a process for collecting data and information needed in a training program. Training evaluation has a function to control the process of the results of the training program so that a systematic, effective and efficient training program can be guaranteed. Accordingly, the evaluation in this study was only carried out in three stages, as follows:

First, Reaction Evaluation; evaluation on the training participants reaction means measuring customer satisfaction. The training program is said effective when the training process is felt to be fun and satisfying for the participants so that they are interested, motivated to learn and practice. The measurement of participant satisfaction level was carried out through the measurement on several aspects of the training. It included interest in training material, training facilitators, training tools and equipment, and aspects of usefulness. The instrument used to measure the level of satisfaction or response of participants to the implementation of training in an effort to empower copra farmers was a closed questionnaire.

Second, Learning Evaluation; the participants are said to have learned if they have changed their attitude, improved knowledge and improved skills. The learning aspects evaluated in this training were cognitive aspect, psychomotor aspect (technical skills), and affective aspect (attitude). These evaluations were carried out by the training facilitator. Cognitive aspect is the level of participant's understanding of the material that was delivered during the training. Psychomotor aspects were related to the participants' skills in processing coconut commodities into economically valuable alternative products. The last, affective aspect measured the attitude of the participants during the training, namely the attendance and activeness of the participants. The way to evaluate cognitive and psychomotor aspects was to compare the technical knowledge and technical skills of the participants before and after the training. Cognitive evaluation was carried out by oral interview, and scoring participants' answers according to the assessment guidelines (rubrics) that have been prepared. Evaluation of psychomotor aspects was done by evaluating performance (practice). The instrument used to conduct the assessment was an observation sheet (observation sheet), while the assessment of the attitude aspects or affective was done through observation (observation) during the learning process.

Third, Product Evaluation; the effectiveness of copra farmers' empowerment through training was not only assessed in learning but also in the improvement of the quality of alternative coconut commodity products produced by the training participants. The product evaluation was done by comparing products before and after training. The products evaluation used an instrument, namely a product 
assessment sheet that has been previously prepared by the facilitator.

Expert Validation Analysis, before the empowerment model was applied, the first thing to do was doing experts validation for the mode. The first validation was a validation from practitioners. The chosen practitioner was the Coordinator of Village Empowerment Department. Practitioner was chosen because the researchers thought that the coordinator had knowledge and experiences as well as often directly interacted with copra farmers' community. the questionnaire provided for the practitioner contained two aspects and 13 indicators. Besides, the model was also validated by academics. There were two people majoring in economics field asked to be the academics validator. Those people have handled professorship and doctorate titles. For academics experts, the questionnaire consisted of seven indicators. Further, the results of experts validator can be seen in the following figure 2 .

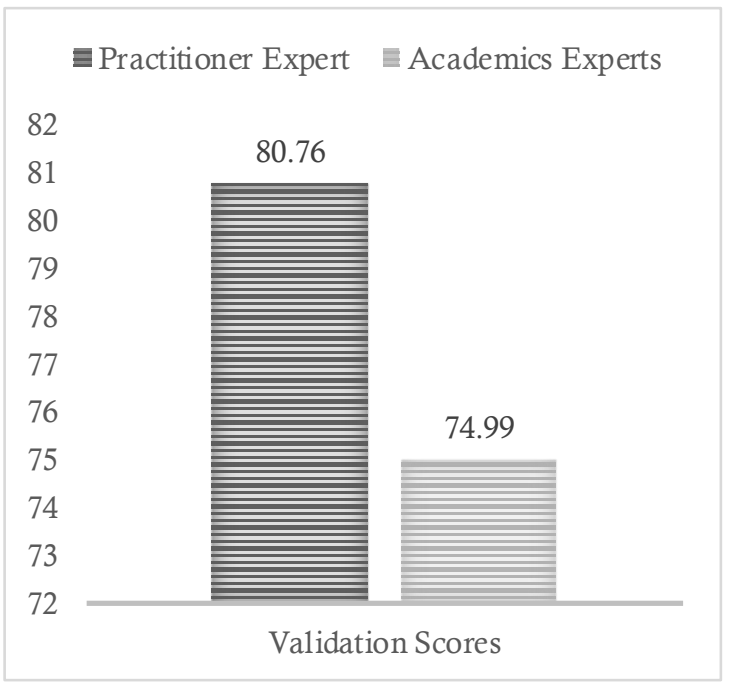

Figure 1. The Results of Validation from Experts on the Copra Farmers Empowerment Model Source: Primary data processed, 2019

Based on the results of experts' validation, the model obtained validity percentage of $80.76 \%$. It meant that the model can classified into good category and valid. Moreover, the results of practitioner validation also showed no revision. Meanwhile, the academics validation gave $74.99 \%$ validity to the model. It meant that the model for copra farmers' empowerment can be classified into good category and valid. The experts also gave no suggestion to revise the model. At last, the validation results from all experts indicated that the model for the empowerment of copra farmers was valid and feasible to implement.

\section{CONCLUSION}

Based on the results and discussion chapter, it can be concluded that the problems faced by copra farmers in Asimiro Village are the limited capital, conventional technology, and marketing that still depends on collectors. The model for training program for farmers' community empowerment in Asimiro Village was written based on the results of interview done in the field study (information collection stage). There were several community empowerment programs implemented through training and socialization in Asimiro Village, namely: 1) program for the development of coconut and onion cultivation through the socialization from the Agricultural Technical Service of North Halmahera Regency; and 2) Program Peningkatan Kesejahteraan Petani (PPKP) through training and socialization of "dapur sehat" (healthy kitchen) conducted by the Village Community Empowerment Agency in collaboration with the Family Planning Agency. The results of expert practitioner validation for the model gained the percentage of $80.76 \%$. Meanwhile, the academics validators gave $74.99 \%$ for the model.

It shows that the model for the empowerment of copra farmers in this study can be classified into good category and valid. The government needs to pay special attention to copra farmers considering that their level of empowerment is still low. From the results of the study found an appropriate empowerment model is training for copra product diversification. So the assistance that needs to be emphasized is to focus on improving the skills and skills of farmers. This research still has limitations in the form of research focus which is only focused on one village, namely Asimiro Village. It is hoped that there will be further research examining with a broader scope in Halmahera Regency. 


\section{REFERENCES}

Aminah., S. et al. 2015. "Factors Affecting Peasants' Empowerment in West Halmahera District - A Case Study From Indonesia". Journal of Agriculture and Subtropics, 116 (1) 11-25.

Budiman, C, Massie, J, Wullur, M. 2015. Identification of copra supply chain management network design in the city of Manado (studies in the bengkol and tongkaina villages). EMBA Journal. 3 (2): 65-76

Chaerani, Dang Sri. 2016. Copra Marketing Margin and Efficiency in Simalegi Village, West Siberut District, Mentawai Islands Regency. Bibiet Journal. Vol 1 (2). PP 81-94.

Hishiyama, R., 2013. "Sustainable Empowerment Models for Rural Pastoral Communities in Kenya". Procedia-Social and Behavioral Sciences (85) 432-442.

Kartasasmita, G. 1996. Development for the People: Integrating Growth and Equality. Jakarta: CIDES

La Idin. 2016. Analysis of Labor Productivity in Copra Processing in Raha City. UHO Economic Journal. 1 (1): 155-165

Lay, A., \& Install, M.P. 2012. "Strategy and Implementation of Future Coconut Product Development". Journal of Perspective, 11 (1): 0122.

Mardikanto, T., \& Soebianto, P. 2017. Community Empowerment in Public Policy Perspectives. Surakarta: Alfabeta.

Patty, Z., 2011. "Analysis of Productivity and Added Value of People's Coconut (Case Study in Three Districts of North Halmahera Regency", Agroforestry Journal, 6 (2): 154-159.

Halmahera Regency Government, 2016. 2016 Annual Report Responsibility Report (LKPJ).

Pohan, I, P, Sihombing, L, Sebayang, T. 2013. Analysis of added value and marketing of copra (case study of new silo village, subdistrict of sea glare asahan district). Journal on Social Economics of Agriculture and Agribusiness. 2 (9): $1-15$

Popoko, S. 2013. The effect of marketing costs on the level of copra farmers' income in the southern district of Tobelo, North Halmahera Regency. Journal of Uniera. 2 (2): 80-91

Rifa'i, Ahmad, Wandi \& Muhammad Rasyid Ridha. 2019. Training on White Copra Processing. Values: Journal of Community Service. Vol 1 (1). Pp. 42-51.
Rosidi, Asri Rachmat., Siti Asmaul Mustaniroh, \& Panji Deoranto. 2017. Planning of Development Strategy in Copra Agroindustry (Case Study in East Halmahera Regency). Journal of Agricultural Technology. Vol 18(3). Pp. 211-244. Rusno, A, L, Laoh, O, E, H, Wangke, W, M, Tangkere, E, G. 2014. Relationship of Copra Prices To Copra Production Level in South Minahasa Regency. COCOS. 4 (3): 1-11

Sutardi., At al. 2017. "Central Maluku Community Empowerment to Achieve Integrated and Sustainable Coconut Processing SMEs". UNS SME's Summit \& Awards 6th National Seminar.

Wardanu, A, P, Anhar, M. 2014. The strategy of developing coconut agro-industry as an effort to accelerate the community's economy in Ketapang District. Journal of Industry. 3 (1): 1326

Zunaidah, Farida Nurlaila \& Mohamad Amin. 2016. Developing The Learning Materials Of Biotechnology Subject Based On Students' Need And Character Of Nusantara Pgri University Of Kediri. Indonesian Biology Education Journal. Vol 2 (1): 19-30 